Ribeirão Preto, 16 de julho de 2002

Prof. Dr. Harley Bicas

Editor

Arquivos Brasileiros de Oftalmologia

Prezado Editor,

\section{PHD ou D?}

Essa correspondência tem por objetivo discutir alguns aspectos da carta do Prof. Rubens Belfort Mattos Jr. publicada no último número dos Arquivos.

Inicialmente gostaria de me solidarizar com o autor no tocante ao problema da participação de alguns de nossos colegas em Congressos nacionais e internacionais. $\mathrm{O}$ absenteísmo injustificado de palestrantes é intolerável. Como exorganizador de várias reuniões científicas em Ribeirão Preto, já fui vítima desse tipo de atitude e posso garantir que a sensação é bastante desagradável. A organização de congressos exige um tremendo esforço por parte das pessoas que estão na comissão organizadora e quando um palestrante já compromissado com o evento não aparece, a frustração é grande. Quando a ausência se dá em um congresso internacional, o problema é ainda maior, pois é a reputação do país e, por conseguinte de todo nós, que é afetada.

Em relação ao segundo tópico da carta, o uso no Brasil da abreviatura "PhD" por parte de oftalmologistas que detêm o título de Doutores strictu sensu, vou discordar do autor, pois acredito que o Prof. Belfort está adotando uma posição dogmática e simplista.

Afinal qual é o problema das três benditas, ou malditas, letras PhD? Se elas significam Philosophiae Doctor (nesse ponto eu concordo inteiramente com o Prof. Rubens) por que só os que obtiveram Doutorado em biologia, farmacologia, fisiologia, saúde pública e coisas afins têm o privilégio do prestigioso apêndice e aqueles que obtiveram o mesmo título em áreas como Medicina, Engenharia, etc. não podem usá-las? Afinal o que filosofia tem a ver com saúde pública?

Como os oftalmologistas brasileiros que têm doutorado utilizam (a meu ver corretamente) o dito cujo apêndice quando escrevem em inglês e geralmente para americanos, convém examinar como e porque as três famosas letras foram parar nos Estados Unidos.

Essa questão foi longamente explicitada no famosíssimo parecer 977/65 do Conselho Superior de Ensino do MEC, aprovado em 3/12/1965 e de autoria de um time de peso-pesados da intelectualidade brasileira de todos os tempos: Almeida Júnior, Newton Sucupira, Clóvis Salgado, José Barreto Filho, Maurício Rocha e Silva, Dumerval Trigueiro, Alceu Amoroso Lima, Anísio Teixeira, Valnir Chagas e Rubens Maciel.

Nos EUA, quando o aluno deixa a High School e ingressa no sistema universitário, ele é obrigado a cursar o College, que é a base comum de estudos de todo o espectro do conhecimento superior. Nesse nível, ele obtém o título de bacharel (BA ou BSc) sendo considerado um under-graduate. Se ele deseja avançar e obter graus superiores de educação ele continua a fazer estudos regulares para obter o título de Master (MA ou MS) e de Doutor ou PhD, tornando-se um graduated. Assim vê-se que aquele que nós chamamos de pós-graduando, eles chamam de "graduando".

Como as três letrinhas foram parar na América? Elas só obtiveram a green card em virtude da influência germânica no ensino superior americano. Com efeito, o College americano corresponde às classes superiores do denominado ginásio alemão. Na Alemanha, o nível universitário sempre foi alcançado com estudos posteriores. Como a primitiva Faculdades de Arte, tornou-se a Faculdade de Filosofia, os alunos que ali eram graduados recebiam o título de Doutor em Filosofia, Philosophiae Doctor (PhD), título que passou a ser conferido em qualquer setor de ciências e das letras. Inspirando-se nessa faculdade, a Graduate School americana é o instituto que se encarrega dos cursos de pós-graduação, o lugar, por excelência, onde se faz pesquisa científica, se promove a alta cultura, se forma o scholar e se treinam os docentes dos cursos universitários (cópia ipsis literis do aludido parecer 977/65).

O sentido moderno de PhD é claro. Ser PhD significa que o indivíduo teve uma formação específica de cunho científico e didático que o habilita tanto ao exercício da docência quanto ao da pesquisa. Ele foi capaz de estruturar um ou mais experimentos, obter conclusões originais e defendê-las formalmente numa tese. Em última análise, ele aprendeu o chamado método científico. Esse conjunto de características, que obviamente é impossível de ser alcançado nos cursos regulares de graduação profissionais (medicina, engenharia, direito), confere àqueles que são $\mathrm{PhD}$ um perfil acadêmico, fundamental para o exercício da pesquisa. A total equivalência entre $\mathrm{PhD}$ e Doutorado é plenamente reconhecida no documento que criou a pós-graduação brasileira, literalmente....nos Estados Unidos, conforme vimos, o doutorado de pesquisa é o PhD, ou seja, Philosophiae Doctor, segundo o modêlo germânico e que se aplica a qualquer setor de conhecimento. Assim, temos o PhD em Física, Sociologia, Letras, Biologia, etc... ou em Filosofia propriamente dita.

Vale lembrar que as três importantes letrinhas não são usadas em todos os países. Na França, cobrindo toda a área 
das Ciências e Humanidades há respectivamente o Docteur en Sciences e o Docteur des Lettres. Na Alemanha, há o Dr. Philosophiae (relativo a Faculdade de Filosofia), o Dr. Rerum Naturalium (ciências naturais e exatas) e o Dr. Rerum Politicarum (ciências sociais e econômicas), além dos diversos doutorados relativos às profissões liberais tradicionais.

Esse verdadeiro imbróglio de denominações usado para substituir as três letras que nos ocupam, levou a Universidade de São Paulo a exarar uma resolução (CoPGr n ${ }^{\circ}$ 4678/99) para orientar as Câmaras de Pós-Graduação que examinam processos de equivalência de Doutorado. Por exemplo, os títulos franceses de Doctorat de 3éme cycle, Docteur Igénieur e Doctorat d'Université não são reconhecidos como equivalentes ao Doutorado da Universidade de São Paulo. Idem os diplomas de Laurea de Dottore e Baccalaureatum da Itália e os de 1ERE e 2e License da Bélgica.
Em resumo, $\mathrm{PhD}$ e o Doutorado brasileiro traduzem a mesma coisa, isto é, a aquisição do método científico consubstanciado pela realização de uma pesquisa, defendida formalmente como tese. Os oftalmologistas brasileiros quando usam o apêndice $\mathrm{PhD}$ estão dizendo aos seus colegas americanos que eles têm essa formação. A questão histórica relativa ao objeto da tese, se biologia ou óptica fisiológica, é, claramente, irrelevante.

Finalmente, acho que mais importante que questionar se oftalmologistas com Doutorado sensu strictu devem usar o bendito título nos seus artigos em inglês, é saber se eles realmente estão agindo como PhDs. Se eles têm como projeto de vida, a utilização do método científico para o avanço do conhecimento eles são verdadeiros $\mathrm{PhDs}$. Se, ao contrário, eles passam o dia prescrevendo óculos e operando catarata, o título é uma contrafação.

Antonio Augusto V. Cruz

Coordenador do programa de pós-graduação de Oftalmologia da Faculdade de Medicina de Ribeirão Preto - USP, Membro da Comissão de Pós-Graduação da Faculdade de Medicina de Ribeirão Preto - USP e,

last but not least, PhD.

\section{ABO ELETRÔNICO}

Novo site

Acesso: http://www.abonet.com.br 